\title{
Participatory Action Research in University Chemistry Teacher Training
}

YANNIK TOLSDORF ${ }^{1}$ AND SILVIJA MARKIĆ ${ }^{\star 2}$

$\approx$ The Participatory Action Research (PAR) model developed by Eilks and Ralle is very well known in science education. Over the years, many teaching and learning materials have been developed and implemented in German secondary schools using this method. The success of the model encouraged us to adapt it to the university level in order to develop university chemistry education courses. However, to do this, we encountered and conquered some challenges. The present paper is based on an advanced model of Participatory Action Research for developing university chemistry teacher training. For an advanced model, the focus is strongly on the extended development team, which contains people who were not part of the original team. The role of the students also changes. The ideas we used to further develop the model and implement it in practice will be described and discussed below.

Keywords: model, participatory action research, university chemistry teacher education 


\section{Participativno akcijsko raziskovanje pri izobraževanju učiteljev kemije}

\section{YANNIK TOLSDORF IN Silvija MARKiĆ}

$\propto$ Model participativnega akcijskega raziskovanja, ki sta ga razvila Eilks in Ralle, je zelo dobro poznan v naravoslovnem izobraževanju. Skozi leta je bilo v nemških srednjih šolah razvitih in implementiranih veliko materialov za poučevanje in učenje $\mathrm{z}$ uporabo te metode. Uspeh tega modela nas je spodbudil, da smo ga prilagodili univerzitetni ravni z namenom razvoja predmetov na področju kemijskega izobraževanja. Da smo to naredili, smo se spoprijeli $z$ nekaterimi izzivi in jih tudi uspešno rešili. Ta prispevek temelji na naprednem modelu participativnega akcijskega raziskovanja, ki omogoča razvoj poučevanja učiteljev kemije. Za napredni model je značilen fokus na razširjeni razvojni skupini, $\mathrm{v}$ katero so vključeni ljudje, ki niso bili del prvotne skupine, ki je razvijala ta model. Tudi vloga študentov se je spremenila. Ideje, ki smo jih uporabili za razvoj modela in njegovo implantacijo v praksi, so opisane in obravnavane v prispevku.

Ključne besede: model, participativno akcijsko raziskovanje, univerzitetno izobraževanje učiteljev kemije 


\section{Introduction}

Diagnostic competence is one of the primary competences that future teachers, in general, and future chemistry teachers, in particular, should possess. This competence is needed whenever one deals with heterogeneity, models of lesson design, and issues of individual support (e.g., Heritage, Kim, Vendlinski, \& Herman, 2009; Herman, Osmundson, Dai, Ringstaff, \& Timms, 2015; Loughran, Berry, \& Mulhall, 2006; Shulman, 1987). In general, diagnostic competence is described as knowledge about students' learning conditions, their social skills, and their evaluation of any other students' activities in the classroom. In addition, it is essential for the appropriate diagnosis of students' learning conditions, including any obstacles for successful learning (Tolsdorf \& Markic, 2016). Diagnostic results and observations help chemistry teachers in their lesson planning and, thereby, in the analysis and development of their own lessons (Klug, Bruder, Kelava, Spiel, \& Schmitz, 2013). Jäger (2006) described diagnostic competence as mainly based on the following knowledge domains: (i) Conditional Knowledge, (ii) Technological Knowledge, and (iii) Knowledge of Change. Conditional knowledge is knowledge about the background of one given person, any influences that affect personal experiences, and those that cause certain behaviours. In addition, this also includes the knowledge of such effects and their possible manifestations in a particular survey. The aspects of heterogeneity and diversity belong to this knowledge domain. Technological Knowledge involves the ability to select the most appropriate data collection and analysis methods for diagnostic questions. Finally, the Knowledge of Change means any knowledge that allows the teacher to apply strategies dealing with changing the learning experience and/ or the behaviour of anyone involved in the interactions (Jäger, 2006).

Thus, diagnosis is an essential and central issue in the work of teachers. It becomes even more difficult in the larger, complex structure of learning and teaching (Brante, 2009). Since the importance of diagnostic competence increases with a corresponding rise of diversity and heterogeneity in schools, a need to include diagnostic knowledge in higher education courses exists. But how can we integrate and implement such new aspects into teaching in higher education?

\section{Participatory Action Research for Secondary schools by Eilks and Ralle}

The origin and history of Action Research are somewhat unclear. McKernan (1991) has identified action research as a method from the origin of science in education in roughly the late $19^{\text {th }}$ century. For Kemmis, McTaggart, and 
Nixon (2014), the classical action research model by Lewin remains a cyclical development process with four phases: 1) Planning or Development, 2) Action, 3) Observation, and 4) Reflection. These represent easy and helpful steps for a communicative development process (Altrichter, Kemmis, McTaggart, \& Zuber-Skerritt, 2002). They were adapted in the model by Eilks and Ralle (2002).

The Model of the Participatory Action Research by Eilks and Ralle (2002) has had success in the development of new and innovative teaching materials. It is a development model for the school context, in which in-service practitioners and experts (theoreticians) work together communicatively and equally to better teaching practices (see also Eilks, Parchmann, Gräsel, \& Ralle, 2004). Many materials have been developed with this model over a broad period (Eilks \& Markic, 2011; Markic \& Eilks, 2006). In the school context, positive experiences have been collected and documented in many publications (Eilks, Markic, \& Witteck, 2010; Valanides, Nicolaidou, \& Eilks, 2003). The model of Eilks and Ralle (2002) is presented in Figure 1.



Figure 1. Participatory Action Research by Eilks and Ralle (2002, p. 82).

Furthermore, Eilks and Ralle (2002) adapted the continuous, cyclical process mentioned above. The development of new materials and the research of practice, therefore, consist of a multi-step process. The aim of cyclical 
development is the 'conception and knowledge for the development of teaching practice' and the 'development of concrete practice by the research process' (Eilks \& Ralle, 2002, p. 89). Additionally, it is of fundamental interest to the present model to positively change teaching practices. The problems found in current practices should be minimised or even solved in multiple cycles, with the help of stepwise changes in practice (Eilks \& Ralle, 2002). Cooperation between two types of groups, practitioners (chemistry teachers) and researchers (chemistry educators) is essential.

There are several different models of action research (e.g., Holter \& Schwartz-Barcott, 1993; Kemmis \& McTaggart, 1988). Masters (1995) differentiated models of action research in three types and described three new types. Moreover, these types of action research are connected to the present research perspective:

1. scientific-technical view of problem-solving: the researcher takes the lead in the main part of the developmental process and brings new ideas (e.g., research question, strategies, new materials) into the process. Furthermore, the researcher has the task of evaluating the 'new' practice. Here, the practitioners are on hand to help the researcher and to field test the materials in everyday practice.

2. practical-deliberative action research: all the people involved cooperate more and more in the developmental process. The practitioners participate in development and testing. Here, the researcher only starts the development process with a problem from teaching practice.

3. critical-emancipatory action research: the practitioners and researcher have equal rights, but the practitioners take the lead in the main part of the developmental process. The researcher is more of a support aid for development, and the practitioners participate in all steps of the development process. Therefore, the problems come directly from the practitioners themselves.

The Participatory Action Research model of Eilks and Ralle (2002) adheres more to the second type of research above, since the practitioners and researcher are equal, but an initial question from the researcher instigates the whole action of the development process. Eilks et al. (2004) state that the development team and the tasks in the team can change over time, as can the type of action research. The different characteristics of the people involved influence the development of materials. They thus represent a mixture of various teaching experiences, didactic and methodological experience, knowledge about the learning process, and creativity. 
The development process consists of many successive cycles. It can be divided into three phases in which the cycles have differing priorities. The development team is small in the first phase. It gains awareness of the problem and discusses any relevant subject knowledge and the pedagogical background. Initial approaches are developed in the team and tested in each small group (Eilks \& Ralle, 2002). New practitioners are supposed to be involved in development during the second phase. This expands the practice field and yields new approaches from the practitioners that can enrich the overall development of teaching practices. A wider evaluation is carried out in multiple groups at the end of this phase. After this, the third phase begins with the examination of whether or not the new approaches have been sufficiently well-documented, so that they can be used without the more detailed supervision of the practitioners in lessons (Eilks \& Ralle, 2002).

\section{Challenges in the adaptation from the school level to higher education}

Because Participatory Action Research (PAR) at the secondary school level was able to collect positive experiences and create many useful materials, the idea of adapting the model for the development of university-level, chemistry education seminars arose. Additionally, several initial projects for developing chemistry education already exist and have yielded positive results (Burmeister \& Eilks, 2013; Krause \& Eilks, 2015). Thus, the focus of the present study is the adaptation of the model of Participatory Action Research of Eilks and Ralle (2002) for the development of university chemistry teacher training. What such an adapted model looks like is to be determined.

However, we encountered some adaptational challenges with our model for higher education, which had previously been advantages when working with the original Participatory Action Research model. These occurred as we started developing teacher-training modules for chemistry, which focused closely on diagnosis and support. These challenges have already been documented for two previous projects (see Burmeister \& Eilks, 2013; Krause \& Eilks, 2015).

The original model set clear distinctions between the in-service personnel (teachers) and the theoreticians (university chemistry educators). However, both groups were now represented by one person in the new university model. On the one hand, the chemistry educator leads the practitioners in the chemistry educational modules; on the other, he or she is also a researcher in this field. This causes limitations that should be considered during development. Furthermore, a radical redefinition of the original model of Eilks and Ralle (2002) 
had to be faced, since only two people were sufficient for the developmental process. This meant that the chemistry educator could develop the materials independently. However, this does not fulfil the spirit of Action Research, in which the developmental team employs a larger group creating productive, communicative exchanges during the developmental process.

As for implementing the material, at the University of Bremen, the relevant seminars are offered annually and are attended by small groups of student teachers. It is difficult to find parallel groups researching the same topic, since most universities in Germany do not have the same curricula for their university teacher-training programmes. Thus, involvement in a wider field of practice is limited and remains difficult. However, the feedback provided by student teachers is essential.

This approach places the focus on developing diagnostic competence in our seminars. It is crucial to remember, however, that such competence is less in line with the main focal points in chemistry education. As important as diagnostic ability is for teachers, this area is more represented by educational aspects found in such subjects as psychology, German language teaching, and special needs education. However, this also means that focussing solely on the goals and topics of a normal university chemistry education would deprive all chemistry teachers and educators almost entirely of the necessary competencies and helpful knowledge to be found in this vital field. Therefore, a mix is fundamentally necessary.

\section{Extended development team}

Starting with the challenges above and the pitfalls faced by a strictly onediscipline approach, the development team needed to be reformed. To prevent the researcher from being placed in a double role, more university faculty must be involved in the development. Other subject disciplines and closely related research domains with regard to the issue should be integrated into the development team. The chemistry educator who will teach the seminar serves as the practitioner in the original model. This person intimately knows the old course and has detected a problem in his or her own teaching that needs to be solved or minimised. The various experts in the group have different and deeper understandings and knowledge about various aspects of the topic. Furthermore, this group possesses a large pool of theoretical knowledge. The other people involved bring new practical and theoretical knowledge, thereby enhancing the overall view of new methods, theories, and opinions for the developmental process (see Reinhardt, 2009). Through this extension, subjective theories can influence the 
development of materials, and these theories exist parallel to the scientific theories. Both types of theories from chemistry educators can, therefore, influence each other (Baumert \& Kunter, 2006) and lead to otherwise unexplored results. Specific subjective theories are activated by certain actions, and these (along with other factors (e.g., emotional aspects to the problems)) influence the actions, behaviour, and practical work of the participants (e.g., Aquirre \& Speer, 200o; Mansour, 2009). This allows the theories to influence development. Furthermore, attitudes and subjective theories differ between chemistry educators, because they depend on personal, practical experience (Fussangel, 2008). Finally, Feldmann (1996) and Bencze and Hudson (1999) have documented a change in practical knowledge during this process, which helps to improve all of the participants' teaching practices. Thus, educators from similar disciplines (biology, physics) should also be included in the development process.

Diagnostics and heterogeneity tend to be less the focus of chemistry teaching and chemistry education; they are more likely to be found in the disciplines of pedagogy or special needs education. This obviates the involvement of educators from language learning, pedagogy, or inclusive education. The involvement of researchers from outside the science education realm should be tailored to the problems. This type of group parallels the original model by Eilks and Ralle (2002) more closely, because such people possess a deeper knowledge of diagnostics and heterogeneity, two topics which are relative newcomers in chemistry education. Moreover, experiences and teaching attitudes can also positively affect the development process. According to Markic, Broggy, and Childs (2013), language plays a central role in the acquisition of knowledge and promotion of communication in science teaching. Thus, language and linguistic promotion aspects should be integrated into chemistry teacher-training programmes. This consequently means that German educators and German-as-a-second-language (GSL) educators participate actively in the development team.

Reinhardt (2009) also describes a discrepancy between teachers as practitioners and researchers as pedagogical theoreticians (see also Huberman, 1993). He concludes that teacher-training programmes must respond to this discrepancy. Both perspectives need to be considered in education. Teachers have the general pedagogical knowledge to design and plan lessons, which depends on their personal experience. On the one hand, this knowledge also means organisational and methodical knowledge for particular classroom actions; on the other, it includes concrete strategies and methods for lesson planning (Baumert \& Kunter, 2006). Teachers also have specific beliefs and attitudes about learning and teaching (Fussangel, 2008). Additionally, post-university student teachers are exposed to this at school during their final teacher training. This ensures that they are not 
shocked by real-world learning situations, and it makes the transition from a life of study into the workaday world easier. This process must also be actively supported by university teachers. This can be done by including teachers' attitudes, beliefs, and subjective theories into the curriculum at the university (Schüssler, Keuffer, Günnewig, \& Scharlau, 2012). Thus, experienced teachers should also be involved in the development of university teacher training.

Finally, student teachers themselves should be involved in the development of their education. Teacher trainees have the same role as the students in the original model and, consequently, they help to test the developed materials from the university in their classrooms. The German Federal Ministry of Education and Research (BMBF, 2009) has previously remarked that university students are rarely or insufficiently in contact with their professors. Their courses are rarely adapted to the students' needs and attitudes. Moreover, student teachers' task does not only consist of testing new materials at the university. It also entails reflection upon these materials and giving personal feedback about them. Trainees are supposed to enlarge the overall picture presented by the materials, provide feedback to the entire group, and initiate rapid intervention in the developmental process. The student teachers are an integral part of the development team.

To summarise, an overview of the formation of the development team is presented in Figure 2.

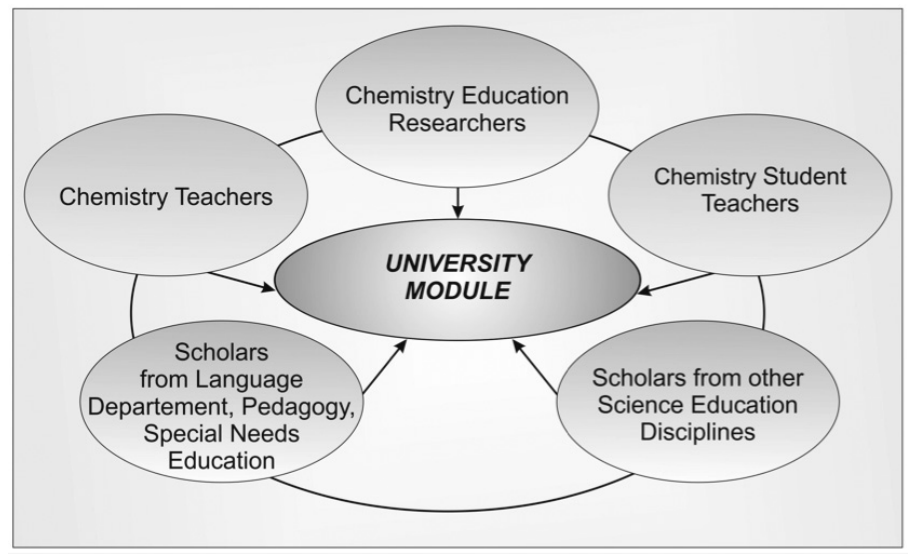

Figure 2. Groups involved in the development team for university courses.

Because such multi-faceted composition of the teams has to be deduced from the theory, the resources available significantly influence the development process. This allows the mixing of two contrary knowledge domains (empirical 
research results and practical experience), which has already been mentioned in the literature (McIntyre, 2005). Other significant aspects include the summarisation of teaching experiences, the inclusion of intuitive action skills, the use of unlimited creativity, and the harnessing of the diverse academic backgrounds among the people involved.

\section{The developed model of Participatory Action Research for higher education}

We also adopted the idea of a cyclical process and a multi-step development process with four phases for the creation of university courses. This means that an initial problem is detected by the chemistry educator, who is also the lecturer in the chemistry educational course. To ensure that the problem is not simply a one-off situation and ascertain whether rectification of the problem provokes general interest, the experts first discuss the problem. At the beginning of the process, the development team consists of chemistry educators, chemistry teachers, and educators from other scientific disciplines. An analysis of the relevant literature also has to be made. These first two steps of initiating the development process are also described by Eilks and Ralle (2002). The literature review is continuously carried out throughout the developmental process work. All information obtained is provided to the complete study group (Burmeister \& Eilks, 2013). At the same time, the student teachers also discuss the problem to ensure that it is also observable in daily practice from their side.

The development team has to be put together based on the initial problem and the competencies or skills that are needed to solve the problem. Therefore, team construction represents a main part of the advanced model. All members of the teams are not necessarily active in testing the materials. Some individual members, therefore, take a cooperative, advisory function in the development team. However, it is necessary for the development process that all questions arising during the development process are made accessible to the complete group. The chemistry educators, chemistry teachers and the chemistry student teachers are always involved in development and, thus, form the core of the team.

Team building has become the main role in this model, because the group of people has changed noticeably. Therefore, the team is constructed before the cyclical development process starts. The decision regarding which experts to invited into the team depends directly upon the question at hand.

After the formation of the team, the development of the teaching module, the materials, and the cyclical development routine begins. Courses will be gradually updated and changed, thus minimising and possibly eliminating the problem 
of the course. The changes and development may contribute to the production of new approaches and media offerings. General knowledge and experience are collected about the overall learning and teaching processes at the university. The team begins to develop concrete materials through communicative exchange. This produces preliminary teaching materials and teaching media that are then used in practice at the university. The development team plans the practical use and selects the type of practical experience that is to be the object of consideration in the development process. After testing, each of these steps is analysed and evaluated. Just like with the model for the secondary school context (see Eilks \& Ralle, 2002; Elliot, 1991; Feldman, 1996), an appropriate evaluation method is also selected for the university model. The collected information, practical experiences of the educators, and the overall success or failure of the lessons must all be considered in the further development process. New problems can arise during the reflection phase, which involves the formation of a new team and starts the process from the beginning. Thus, new problems may require the invitation of new members into the development team. An illustration of the enhanced model of Participatory Action Research at the university level is shown in Figure 3.

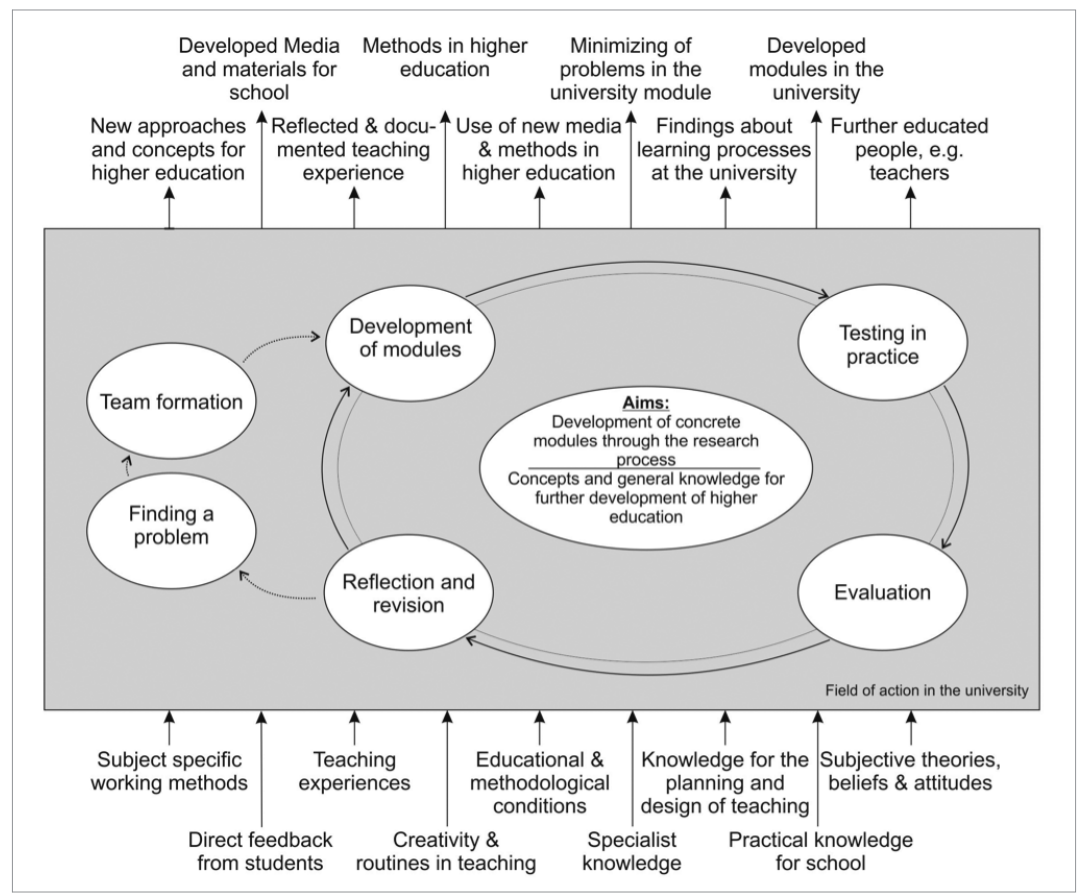

Figure 3. Model of Participatory Action Research for the development of university teaching. 
The result of the development process is new teaching materials, media, and methods for university lessons, but materials for secondary school can also arise. The problem from the seminar has been reduced or eliminated, which begins the developmental process again. In addition, the group obtains many documented and reflected experiences from teaching at the university. The original model of Eilks and Ralle (2002) states that teachers can also learn during the development process. For our new model, this means that all shareholders can learn something from each other. This only describes a part of the final output from development, but the most important aspects are summarised in Figure 3.

\section{An example of development in sensitising students to linguistic heterogeneity}

Up to this point, the newly developed model has been described for the general development of university courses in chemistry. The general description helps to adapt the model to the older version. Furthermore, the development team possesses sufficient freedom during the development process, so the process is not limited.

The following example illustrates the development process and the use of the current model. This example concerns linguistic heterogeneity in chemistry with a focus on reading strategies. One chemistry educator noticed that student teachers needed knowledge about tools to help their future students in reading and understanding scientific literature (including worksheets). Coincidentally, chemistry teachers named various problems that they had observed among their own students when reading scientific texts. During the first phase, the development team (a chemistry educator, chemistry teachers, and one other science educator) discussed the problem intensely. In the first meeting, the team classified several problem areas. The chemistry educators recognised the importance of this issue for their teacher-training programme, especially for chemistry teachers. A literature review of this problem revealed that German education teaches various reading strategies, but only for short stories, newspaper articles, and longer texts. However, the texts in science lessons are different than these text types. This made the easy transfer of the reading strategies to science texts next to impossible. For this reason, a researcher from the GSL department was invited to visit the team. The researchers explained the problems that had been identified, including one with concrete texts taken from science teaching and examples selected from chemistry lessons. Their first aim was to develop reading strategies specifically for understanding scientific texts. The reading strategies from German education were adapted to the scientific texts. 
In the next step, these tactics were incorporated into the university seminar for chemistry teachers. The seminar was then evaluated with the help of a questionnaire. The whole group also reflected upon the seminar.

One main result of the reflection was the fact that most student teachers could not recognise a need for reading strategies in chemistry lessons. Student teachers often feel that addressing linguistic problems does not fall under the list of the responsibilities of chemistry teachers. The new materials were developed; but a new problem, which seems more fundamental, arose. Student teachers' attitudes needed to be changed. Thus, the team was expanded by another language educator. The aim was to develop a seminar with regard to sensitisation for linguistic heterogeneity. Finally, the reading strategies became one among many aspects of the seminar. The seminar was organised in several phases and was structured as follows:

1. Sensitising student teachers for linguistic heterogeneity in chemistry classes (e.g., by reading and analysing specialised texts from business, economics, or psychology; lecturing in English instead of German, etc.);

2. Recognising the problem based on authentic teaching material (working on material taken from chemistry textbooks and analysing them with a focus on linguistic heterogeneity in chemistry classes);

3. Learning about reading strategies in science teaching (learning-at-stations exercises about different reading strategies (compare to Markic \& Baginski, 2014));

4. Developing teaching materials with reading strategies (integration of reading strategies in concrete materials).

During the last reflection exercise in the group, which took place during group discussion time in the seminar with the help of a Likert questionnaire, the chemistry students who had participated in the seminar gave feedback. They stated that they now understand the need for special reading strategies and that they would use them during their next internship at school. The development process is presented again in Figure 4. 


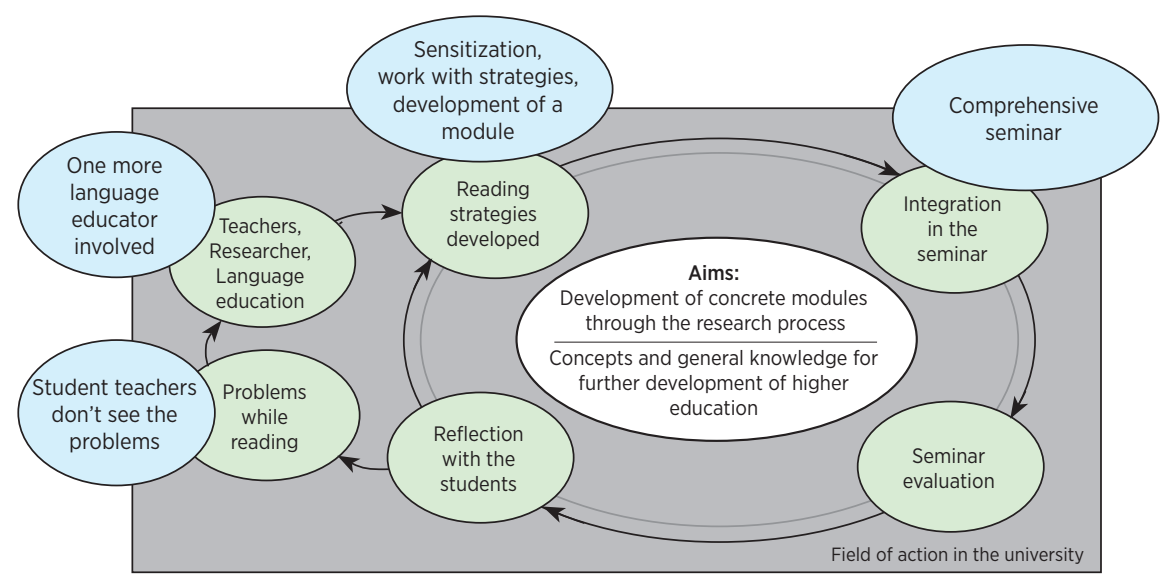

Figure 4. The development process of a university course for linguistic heterogeneity.

\section{Phases of Participatory Action Research}

In the original model of Participatory Action Research of Eilks and Ralle (2002), the authors proposed a division of development into three phases. Because of the challenges to the adaptation of the original model to the university level, a different split of the developmental phases was proposed at this point. This was also caused by the limited number of available educators for a given subject at university, especially in chemistry education.

The first phase of the new model starts with team building, which is dependent on the problem and thus on the competences single members of the team need to have. This initial development team is relatively small and can be enlarged as needed during the development process. In this phase, the focus is on the problem, the teams' available content knowledge, and its ' pedagogical content knowledge. This means that agreement on particular terms and terminology must be accomplished. At the end of this phase, initial approaches and materials are developed. One characteristic of this phase is very frequent, often significant modifications of media, materials, and concepts.

In the second phase, the initially developed materials, media, and concepts are differentiated, developed, tested, and evaluated. Ideally, the testing should be performed by several university course groups. In this phase, the implementation of the materials is the focus.

In the third phase, all the newly-developed materials are disseminated. These materials can be used in further lectures or in courses at other universities. Implementation at other universities offers the opportunity that the 
materials be developed afresh and ensures the parallel dissemination of the materials and media to a broader group of participants. Ideally, this expansion could go on to form university (or even international) networks researching the same questions. In each of these three phases, the development process can consist of multiple development cycles, as seen in Figure 2 (Development, testing, evaluation, reflection).

\section{Discussion and Conclusion}

The development of one's own teaching at the university level through the Participatory Action Research was seen to be significantly influenced by self-reflection upon the practical experiences of the participants in school and at university. In addition, the various members of the development team proved to be successful for the development of university courses. The members differed in creativity, beliefs, knowledge, and attitudes, since they represented a very heterogeneous group (e.g., Fussangel, 2008; Mansour, 2009; McIntyre, 2005). The German Association for Subject Matter Didactics (Konferenz der Vorsitzenden Fachdidaktischer Fachgesellschaften) has also found that a broad network of contacts is important to universities (KVFF, 1998).

By using this model, education can enhance interdisciplinary and interinstitutional networking. The participants can also learn from each other. One criticism might be that a culture of development with lecturers acting within their own seminars may be insufficient to reach the stated goals, since the lecturer is also a practitioner and a researcher. One risk is that close personal involvement might lead the participants' evaluation of their courses to be only superficial. However, were this to be true, they would also fail to reap the benefits of better teaching and learning methods and materials in their own classrooms. Shareholding can also be a powerful motivator. We hold the consequent evaluation and gradual development of university courses to be possible using this new model. Additionally, general knowledge and concepts can be gained, which can further develop other university courses. For this reason, the model presented above helps to successively optimise university teaching modules in chemistry coursework. Our new seminars were giving both theoretical and practical backgrounds of the topic. Furthermore, it was much easier to find the connection from one seminar to the other. Starting from the experts in the development team, we can say that our seminars were showing different perspectives to our further chemistry teachers but also were considering the needs of our student teachers - since they were part of the development team as well. To summarise, previous experiences have been very positive, and the 
involvement of teachers in university development has proven useful for both school education and teacher-training programmes. Science educators can learn new and practical elements of chemistry education through the development process. Therefore, the model created by Eilks and Ralle (2002) can serve both for teacher training and for the Continuous Professional Development (CPD) of educators as well.

However, we must note that work on this model is an additional, timeconsuming task for educators. Furthermore, lecturers need the willingness to change. This is a basic requirement for any development process. Additionally, in-service teachers generally have less time available to research and test further actions when developing university education. This is because the extra time comes on top of lesson planning, teaching, grading, going on excursions, and taking class trips. Therefore, one aim of this ongoing project (in addition to increasing the CPD level of chemistry teachers) should be the development of practical and suitable teaching materials, which can be used by volunteer teachers with limited time to take part in research. A good extension of the development team was the involvement of student teachers in the development process of their own education. Courses should be adapted to the needs, perceptions, performance, and opinions of the students taking part. Conversely, in the future, we must address the question of whether student teachers need more help to better their ability to reflect on their teacher-training. From our experience, however, student teachers' willingness to be involved was great. Their feedback was, in our opinion, very constructive and helpful for future work.

The present paper presented an advanced model of Participatory Action Research in the field of developing university teacher education seminars. The focus of the advanced model is on the formation of the development team. The model itself and an example of the development of one seminar were described. The advanced model gives new opportunities for developing seminars which combine theoretical knowledge and practical experience. All in all, even if following this model means much more work for lecturers, the positive experiences outweigh the effort expended. More learning strategies and materials for the university have been developed with this model and have already been implemented at a second university.

\section{Acknowledgements}

Thanks to Deutschen Telekom Stiftung (German Telekom Foundation) for the financial aid and thus support by the development of the present module. 


\section{References}

Aguirre, J., \& Speer, N. M. (2000). Examining the relationship between beliefs and goals in teacher practice. Journal of Mathematical Behaviour, 18(3), 327-356.

Altrichter, H., Kemmis, S., McTaggart, R., \& Zuber-Skerritt, O. (2002). The concept of action research. The Learning Organization, 9(3), 125-131.

Baumert, J., \& Kunter, M. (2006). Stichwort: Professionelle Kompetenz von Lehrer Lehrkräften [Keyword: Professional competence of teachers]. Zeitschrift für Erziehungswissenschaft, 9(4), 469-520. Bencze, T., \& Hodson, D. (1999). Changing practice by changing practice: Toward more authentic science and science curriculum development. Journal of Research in Science Teaching, 36(5), 521-539. Brante, G. (2009). Multitasking and synchronous work: complexities in teacher work. Teaching and Teacher Education, 25(3), 430-436. Retrieved from http://www.sciencedirect.com/science/article/pii/ So742051X08001704?via\%3Dihub

Burmeister, M., \& Eilks, I. (2013). Using participatory action research to develop a course module on education for sustainable development in pre-service chemistry teacher education. Center for Educational Policy Studies Journal, 3(1), 59-78.

Eilks, I., \& Ralle, B. (2002). Participatory action research. In B. Ralle \& I. Eilks (Eds.), Research in chemical education - What does it mean? Proceedings of the 16 th symposium on chemical education at the University of Dortmund, 22-24 May 2002 (pp. 87-98). Aachen: Shaker.

Eilks, I., \& Markic, S. (2011). Effects of a long-term Participatory Action Research project on science teachers' professional development. Eurasia journal of Mathematics, Science \& Technology Education, 7(3), 149-160. Retrieved from http://www.ejmste.com/Effects-of-a-Long-Term-nParticipatoryAction-Research-nProject-on-Science-Teachers-nProfessional-Development,75196,0,2.html Eilks, I., Markic, S., \& Witteck, T. (2010). Collaborative innovation of the science classroom by Participatory Action Research - Theory and practice in a project of implementing cooperative learning methods in chemistry education. In M. Valencic Zuljan \& J. Vogrinc (Eds.), Facilitating effective students learning trough teacher research and innovation (pp. 77-101). Ljubljana: University of Ljubljana.

Eilks, I., Parchmann, I., Gräsel, C., \& Ralle, B. (2004). Changing teacher' attitudes and professional skills by involving teachers into projects of curriculum innovation in Germany. In B. Ralle \& I. Eilks (Eds.), Quality in practice-oriented research in science education. Proceedings of the 17th symposium on chemical education held at the University of Dortmund, 3-5 June 2004 (pp. 87-98). Aachen: Shaker. Elliot, J. (1991). Action research for educational change. Keynes, UK: Open University Press.

Federal Ministry of Education and Research (BMBF). (Ed.) (2009). Bachelor-Studierende: Erfahrungen in Studium und Lehre: Eine Zwischenbilanz [Bachelor students: experience about study and teaching: interim balance]. Berlin: Federal Ministry of Education and Research. Retrieved from https://www. bmbf.de/pub/Bachelor_Studierende_Zwischenbilanz_2010.pdf

Feldman, A. (1996). Enhancing the practice of physics teachers: Mechanisms for the generation and sharing of knowledge and understanding in collaborative action research. Journal of Research in Science Teaching, 33(5), 513-540. 
Fussangel, K. (2008). Subjektive Theorien von Lehrkräften zur Kooperation [Subjective theories of teachers about cooperation]. Unpublished Doctoral Dissertation. Retrieved from http://elpub.bib. uni-wuppertal.de/servlets/DerivateServlet/Derivate-1129/dgo802.pdf

Heritage, M., Kim, J., Vendlinski, T., \& Herman, J. (2009). From evidence to action: A seamless process in formative assessment. Educational Measurement: Issues and Practice, 28(3), 24-31.

Herman, J., Osmundson, E., Dai, Y., Ringstaff, C., \& Timms, M. (2015). Investigating the dynamics of formative assessment: Relationships between teacher knowledge, assessment practice and learning. Assessment in Education: Principles, Policy \& Practice, 22(3), 1-24.

Holter, I. M., \& Schwartz-Barcott, D. (1993). Action research: What is it? How has it been used and how can it be used in nursing? Journal of Advanced Nursing, 18(2), 298-304.

Huberman, M. (1993). Linking the practitioner and researcher communities for school improvement. School Effectiveness and School Improvement, 4(1), 1-16.

Jäger, R. S. (2006). Der Diagnostische Prozess. In F. Petermann \& M. Eid (Eds.), Handbuch der psychologischen Diagnostik [Handbook of psychological diagnosis] (pp. 89-96). Göttingen: Hogrefe.

Kemmis, S., \& McTaggart, R. (1988). The action research planner (3rd ed.). Geelong: Deakin University Press.

Kemmis, S., McTaggart, R., \& Nixon, R. (2014). The Action research planner: Doing critical participatory action research. Singapore: Springer.

Klug, J., Bruder, S., Kelave, A., Spiel, C., \& Schmitz, B. (2013). Diagnostic competence of teachers: A Process model that accounts diagnosing learning behaviour tested by means of a case scenario. Teaching and Teacher Education, 30, 38-46. Retrieved from http://www.sciencedirect.com/science/ article/pii/So742051X12001503

(KVFF) - Konferenz der Vorsitzenden Fachdidaktischer Fachgesellschaften (Eds.) (1998). Fachdidaktik in Forschung und Lehre [Education in research and teaching]. Kiel: IPN.

Krause, M., \& Eilks, I. (2015). Lernen über digitale Medien in der Chemielehrerausbildung - ein Projekt Partizipativer Aktionsforschung [Chemistry student teachers learn about digital media - a project participatory action research]. CHEMKON, 22(4), 173-178.

Loughran, J., Berry, A., \& Mulhall, P. (2006). Professional learning: understanding and developing science teachers' pedagogical content knowledge. Rotterdam: Sense.

Mansour, N. (2009). Science teachers' beliefs and practices: Issues, implications and research agenda. International Journal of Environmental \& Science Education, 4(1), 25-48.

Markic, S., \& Baginski, K. (2014). Aufgaben leichter verstehen: Lese- und Verständnishilfen zur Bearbeitung von Aufgaben [Easier to unterstand tasks: helps to reading and understanding for working of tasks]. Unterricht Chemie, 142(25), 14-17.

Markic, S., \& Eilks, I. (2006). Cooperative and context-based learning on electrochemical cells in lower secondary science lessons - A project of participatory action research. Science Education International, $17(4), 253-273$.

Markic, S., Broggy, J., \& Childs, P. (2013). How to deal with linguistic issues in the chemistry classroom. In I. Eilks \& A. Hofstein (Eds.), Teaching chemistry - A studybook (pp. 127-152). Rotterdam: Sense. 
Masters, J. (1995). The History of Action Research. In I. Hughes (Ed.), Action research electronic reader. Sydney: The University of Sydney. Retrieved from http://www.aral.com.au/arow/rmasters.html McIntyre, D. (2005). Bringing the gap between research and practice. Cambridge Journal Education, 35(3), 357-382.

McKernan, J. (1991). Curriculum action research. A handbook of methods and resources for the reflective practitioner. London, UK: Kogan.

Reinhardt, S. (2009). Gelingende Lehrerbildung - Professionstheorie und Fachdidaktik, Erfahrungen und Konsequenzen [Successful teacher training - professional theory and education, experiences and consequences]. Journal of Social Science Education, 8(2), 23-31.

Schüssler, R., Keuffer, J., Grünnewig, K., \& Scharlau, I. (2012). Praxis nach Rezept? Subjektiven Theorien von Lehramtsstudierenden zu Praxisbezug und Professionalität [Recipe for practice? subjective theories from student teachers to practice and professionalism]. Schulpädagogik heute, 3(5), 141-161.

Shulman, L. S. (1987). Knowledge and teaching: Foundations of the new reform. Harvard Educational Review, 57(1), 1-21.

Tolsdorf, Y., \& Markic, S. (2016). Dealing language in science classroom - Diagnosing student' linguistic skills. In S. Markic \& S. Abels (Eds.), Science Education towards Inclusion (pp. 23-42). New York, NY: Nova.

Valanides, N., Nicolaidou, A., \& Eilks, I. (2003). Twelfth-grade students' understanding of oxidation and combustion - Using action research to improve teachers' practical knowledge and teaching practice. Research in Science and Technological Education, 25(2), 19-175. 


\section{Biographical note}

YANnIK TolsDorf, PhD, is chemistry and mathematics teacher in Bremen, Germany. He finished his $\mathrm{PhD}$ beginning of 2018 at the University of Bremen. His research interests focus on development of chemistry teacher training program especially focusing on diagnostic in science classes and connection between seminars and internship.

Silvija Markić, $\mathrm{PhD}$, is a full professor for science learning and chemistry education at the Ludwigsburg University of Education in Germany. She works in the field of chemistry teacher education and researches in the didactics of chemistry. Her research interests include science teachers' beliefs and pedagogical content knowledge, linguistic heterogeneity and diversity in chemistry and science education, cooperative learning and alternative teaching methods. 